NASA/TM-2010-216782

\title{
Predicted and Measured Modal Sound Power Levels for a Fan Ingesting Distorted Inflow
}

\author{
L. Danielle Koch
}

Glenn Research Center, Cleveland, Ohio 


\section{NASA STI Program . . . in Profile}

Since its founding, NASA has been dedicated to the advancement of aeronautics and space science. The NASA Scientific and Technical Information (STI) program plays a key part in helping NASA maintain this important role.

The NASA STI Program operates under the auspices of the Agency Chief Information Officer. It collects, organizes, provides for archiving, and disseminates NASA's STI. The NASA STI program provides access to the NASA Aeronautics and Space Database and its public interface, the NASA Technical Reports Server, thus providing one of the largest collections of aeronautical and space science STI in the world. Results are published in both non-NASA channels and by NASA in the NASA STI Report Series, which includes the following report types:

- TECHNICAL PUBLICATION. Reports of completed research or a major significant phase of research that present the results of NASA programs and include extensive data or theoretical analysis. Includes compilations of significant scientific and technical data and information deemed to be of continuing reference value. NASA counterpart of peer-reviewed formal professional papers but has less stringent limitations on manuscript length and extent of graphic presentations.

- TECHNICAL MEMORANDUM. Scientific and technical findings that are preliminary or of specialized interest, e.g., quick release reports, working papers, and bibliographies that contain minimal annotation. Does not contain extensive analysis.

- CONTRACTOR REPORT. Scientific and technical findings by NASA-sponsored contractors and grantees.
- CONFERENCE PUBLICATION. Collected papers from scientific and technical conferences, symposia, seminars, or other meetings sponsored or cosponsored by NASA.

- SPECIAL PUBLICATION. Scientific, technical, or historical information from NASA programs, projects, and missions, often concerned with subjects having substantial public interest.

- TECHNICAL TRANSLATION. Englishlanguage translations of foreign scientific and technical material pertinent to NASA's mission.

Specialized services also include creating custom thesauri, building customized databases, organizing and publishing research results.

For more information about the NASA STI program, see the following:

- Access the NASA STI program home page at http://www.sti.nasa.gov

- E-mail your question via the Internet to help@ sti.nasa.gov

- Fax your question to the NASA STI Help Desk at $443-757-5803$

- Telephone the NASA STI Help Desk at 443-757-5802

- Write to: NASA Center for AeroSpace Information (CASI) 7115 Standard Drive Hanover, MD 21076-1320 
NASA/TM-2010-216782

\title{
Predicted and Measured Modal Sound Power Levels for a Fan Ingesting Distorted Inflow
}

\author{
L. Danielle Koch \\ Glenn Research Center, Cleveland, Ohio
}

Prepared for the

16th Aeroacoustics Conference

cosponsored by the American Institute of Aeronautics and Astronautics

and the Confederation of European Aerospace Societies

Stockholm, Sweden, June 7-9, 2010

National Aeronautics and

Space Administration

Glenn Research Center

Cleveland, Ohio 44135 


\section{Acknowledgments}

I would like to thank Ed Envia, Dan Sutliff, and the AAPL staff. Funding for this research has been provided by the Subsonic Fixed Wing Project which is a part of NASA's Fundamental Aeronautics Program.

This work was sponsored by the Fundamental Aeronautics Program at the NASA Glenn Research Center.

Level of Review: This material has been technically reviewed by technical management.

Available from

NASA Center for Aerospace Information 7115 Standard Drive

Hanover, MD 21076-1320
National Technical Information Service 5301 Shawnee Road Alexandria, VA 22312 


\title{
Predicted and Measured Modal Sound Power Levels for a Fan Ingesting Distorted Inflow
}

\author{
L. Danielle Koch \\ National Aeronautics and Space Administration \\ Glenn Research Center \\ Cleveland, Ohio 44135
}

\begin{abstract}
Refinements have been made to a method for estimating the modal sound power levels of a ducted fan ingesting distorted inflow. By assuming that each propagating circumferential mode consists only of a single radial mode (the one with the highest cut-off ratio), circumferential mode sound power levels can be computed for a variety of inflow distortion patterns and operating speeds. Predictions from the refined theory have been compared to data from an experiment conducted in the Advanced Noise Control Fan at NASA Glenn Research Center. The inflow to the fan was distorted by inserting cylindrical rods radially into the inlet duct. The rods were placed at an axial location one rotor chord length upstream of the fan and arranged in both regular and irregular circumferential patterns. The fan was operated at 2000, 1800, and $1400 \mathrm{rpm}$. Acoustic pressure levels were measured in the fan inlet and exhaust ducts using the Rotating Rake fan mode measurement system. Far field sound pressure levels were also measured. It is shown that predicted trends in circumferential mode sound power levels closely match the experimental data for all operating speeds and distortion configurations tested. Insight gained through this work is being used to develop more advanced tools for predicting fan inflow distortion tone noise levels.
\end{abstract}

\section{Nomenclature}

$\begin{array}{ll}a & \text { speed of sound } \\ A_{m n \mu} & \text { power-effective area for } m, \mu \text { mode, } n^{\text {th }} \text { harmonic } \\ a_{m, n} & \text { direction cosine of } n^{\text {th }} \text {-harmonic, } m \text {-lobe mode, }=\sqrt{1-1 / \xi_{m n}{ }^{2}} \\ B & \text { number of rotor blades } \\ C_{m, n} & \text { amplitude of } n^{\text {th }} \text { harmonic, } m^{\text {th }} \text { mode due to rotor interaction with single vane } \\ C_{m, n} & \text { amplitude of } n^{\text {th }} \text { harmonic, } m^{\text {th }} \text { mode due to rotor interaction with stator assembly } \\ j & \text { index } \\ k & \text { index } \\ m & \text { circumferential mode index } \\ n & \text { harmonic index } \\ q & \text { stator vane index } \\ t & \text { time coordinate } \\ V & \text { number of stator vanes } \\ W & \text { acoustic power } \\ \beta_{q} & \text { (nB-m) } \Delta \theta_{q} \\ \beta_{j} & \text { (nB-m) } \Delta \theta_{j} \\ \theta & \text { pressure field angular coordinate } \\ \mu & \text { radial mode index } \\ \xi_{m n} & \text { cutoff ratio of } m \text {-lobe mode, } n^{\text {th }} \text { harmonic } \\ \rho & \text { density } \\ * & \text { complex conjugate }\end{array}$




\section{Introduction}

If proposed blended wing body concept aircraft featuring embedded engines are to become a reality, engineers will need to have design tools capable of accurately calculating the noise produced by a fan ingesting distorted inflow. Experiments in the NASA Glenn Research Center (GRC) Advanced Noise Control Fan (ANCF) rig are being used to gain insight into the physics of fan inlet distortion tone noise. Data from the experiments in the ANCF are being used to validate several tone noise prediction methods currently under development.

Reference 1 describes an experiment conducted in the ANCF and presents an initial attempt to predict the circumferential mode sound power levels. In that work, cylindrical rods were arranged in circumferentially irregular patterns upstream of the fan rotor, and both far field and in-duct measurements of the sound pressure levels were acquired. As described in Reference 1, extensions were made to the work of Sofrin and Mathews(Ref. 2) to model the noise produced by the asymmetric rod placement. In that attempt, though, absolute sound power levels were not calculated. A dominant term in the equation for estimated sound power level was scaled to match one of the data points, thus anchoring the predictions at to a single measurement so that some comparisons could be made between the differing rod arrangements at a given fan rotational speed.

The present report describes refinements to the methods developed in Reference 1 . The refinements allow one to calculate absolute circumferential mode sound power levels, thus avoiding the need to calibrate the model by anchoring the predictions to a measurement, as was done in Reference 1. By assuming that each circumferential mode consists of a single radial mode (the first one), the cut-off ratios for the first radial can be computed and used in the circumferential mode sound power level calculation. In this way, predictions can be made for various distortion patterns and operating speeds.

This improved method, while still ignoring the contribution from the higher order radial modes, is nevertheless useful for quick, parametric design studies involving inlet distortion patterns. Insight from this work is being used to develop a tone noise prediction code capable of estimating both circumferential and radial sound power levels based on the methodology used in the V072 Rotor/Stator Interaction Code (Ref. 3) for more realistic models of the fan geometry.

\section{Experiment}

The experiment was conducted using the GRC Advanced Noise Control Fan that is housed within AeroAcoustic Propulsion Laboratory (AAPL). The ANCF, shown in Figure 1, is $1.2 \mathrm{~m}$ (48 in) in diameter and the centerline of the fan is $3.0 \mathrm{~m} \mathrm{(10} \mathrm{ft)} \mathrm{above} \mathrm{the} \mathrm{floor.} \mathrm{For} \mathrm{these} \mathrm{tests,} \mathrm{no} \mathrm{stator} \mathrm{vanes} \mathrm{were} \mathrm{installed}$ downstream of the rotor. The rotor had 16 blades set at a $28^{\circ}$ pitch angle for all test conditions.

An Inflow Control Device (ICD) was used to condition the flow entering the fan, removing largescale turbulence and ground vortices. The inlet plane was located $0.92 \mathrm{~m}$ (36.2 in.) or approximately $0.75 \mathrm{~L} / \mathrm{D}$ ahead of the leading edge of the fan at the tip location. The exhaust plane was located $1.2 \mathrm{~m}$ (45.44 in.) or approximately $1.0 \mathrm{~L} / \mathrm{D}$ downstream of the trailing edge of the fan at the tip location. Downstream of the test section, centerbody diameter increases to $0.71 \mathrm{~m}$ (24 in) to mimic a nozzle area contraction, yielding a hub-to-tip ratio, $\sigma=0.500$.

The inflow to the rotor was distorted by installing smooth cylindrical rods upstream of the rotor, as shown Figure 2. Four distortion patterns were tested, as shown in Figure 3, using the 30-rod mounting ring. Table 1 lists the angular position of the rods for each configuration. Data was also collected without the rods in place, denoted Configuration 5 . The rods were $1.27 \mathrm{~cm}(0.5 \mathrm{in})$ in diameter and were $31.75 \mathrm{~cm}$ (12.5 in) long, resulting in a $6.35 \mathrm{~cm}$ (2.5 in) gap between the bottom of the rods and the rotor hub. The centerline of the rods was $14.29 \mathrm{~cm}$ (5.625 in) upstream of the rotor leading edge at the tip, or approximately one rotor chord length upstream. Data was recorded at three speed settings: 1400, 1800, and $2000 \mathrm{rpm}$.

Two 15-microphone arrays were used to record the farfield sound distribution from the ANCF. Farfield microphone measurements were acquired synchronously with shaft speed at a rate of 256 
samples per revolution, which allows for processing up to the $128^{\text {th }}$ harmonic of the shaft frequency, or equivalently, up to the $8^{\text {th }}$ harmonic of the blade passing frequency (BPF) for this test (Ref. 4). Since the focus of this research is aircraft engine fan noise reduction, typically the trends in the first three harmonics are studied the most.

In-duct acoustic pressure measurements upstream and downstream of the rotor were acquired with the Rotating Rake (Ref. 5). The Rotating Rake system is a continuously rotating radial microphone rake that is inserted into the duct, generally at either the inlet entrance or exhaust exit plane. The system utilizes spinning mode theory and Doppler-shift physics to separate circumferential modes and the cylindrical wave equation solution to reduce the radial modes. It provides a complete map of the acoustic duct modal magnitudes and phases present in the fan duct.

\section{Fan Tone Noise Predictions Based on the Sofrin-Mathews Model}

Tyler and Sofrin (Ref. 6) used linear harmonic approximations to describe the unsteady pressure distribution at the interaction plane between the rotor blades and stator vanes. In their formulation, the fan stage is idealized by assuming that it is placed in an infinitely long annular duct, and that the blades and vanes are equally spaced in the circumferential direction. The vane row can be either upstream or downstream of the rotor. In a stationary reference frame, the pressure distribution in the interaction plane is periodic in both space and in time and is represented in terms of Fourier series. Recognizing the implications of symmetrical placement of the vanes and blades, Tyler and Sofrin derived conditions when the circumferential sound power levels are maximized $(m=n B \pm k V)$. Stated in another way, the Tyler and Sofrin expression can be used to identify which circumferential modes, $m$, will be generated in an idealized ducted rotor-stator interaction problem knowing the number of blades, $B$, number of vanes, $V$, and the harmonic index, $n$.

Later, while investigating tones present in cut-off fan stage designs, Sofrin and Mathews (Ref. 2) similarly described the pressure distribution at the interaction plane between a rotor and a stator, assuming the stator vane circumferential locations deviated a small amount from uniform spacing. Removing circumferential symmetry in the vane row complicates the description of the pressure distribution in the interaction plane. Sound power level estimates are needed for each of the circumferential modes in order to determine which mode may dominate.

Reference 1 describes how the Sofrin and Mathews' (Ref. 2) relations could be expressed in a form convenient for representing irregularly spaced vanes without the small deviation angle assumption. One shortcoming in the work reported in Reference 1, though, was that absolute circumferential mode sound power levels were not computed. Rather, a dominant term in the estimated sound power relation was calculated. Values of that dominant term were then scaled so that all the predictions for a single operating condition were anchored to a single data point. However, if one is willing to make an additional assumption, absolute estimates of the circumferential mode sound power levels can be made and comparisons between different operating conditions and varying rod placement can be made.

Sofrin and Mathews (Ref. 2) express sound power in a constant area annular duct with the following equation:

$$
W=\frac{1}{2 \rho a} \sum_{n=1}^{\infty} \sum_{m=-\infty}^{\infty} \sum_{\mu=-\infty}^{\infty} a_{m n \mu} C_{m n \mu} C_{m n \mu}^{*} A_{m n \mu}
$$

Circumferential sound power levels can be estimated if you neglect radial variations in pressure and calculate values of the cut-off ratio for the first radial mode only (for each circumferential mode and each harmonic): 


$$
W=\frac{1}{2 \rho a} \sum_{n=1}^{\infty} \sum_{m=-\infty}^{\infty} a_{m n} C_{m n} C_{m n}^{*} A_{m n}
$$

where, as was described in more detail in Reference 1,

$$
\begin{gathered}
C_{m n} C_{m n}{ }^{*}=\left|\frac{C_{m n}}{C_{m n}}\right|^{2} \\
\left|\frac{C_{m n}}{c_{m n}}\right|^{2}=V+2 \sum_{j>q} \cos \left(\beta_{q}-\beta_{j}\right)=V+2 \sum_{j>q} \cos \left((n B-m)\left(\Delta \theta_{q}-\Delta \theta_{j}\right)\right) \\
a_{m n}=\sqrt{1-1 / \xi_{m n}}
\end{gathered}
$$

\section{Comparison of Measurements and Predictions}

We can now examine the sound pressure and power levels for each rod configuration and for each fan speed. The far field microphone array data is presented in the directivity plots of Figures 4 and 5 . The 1-BPF tone sound power levels are shown in Figures 4 and the 2-BPF tone sound power levels are shown in Figure 5. It is interesting to note that the 1-BPF tone farfield levels for Configuration 2 (6 rods $12^{\circ}$ apart) are consistently lower that the 1 -BPF tone for Configuration 1 ( 6 rods $60^{\circ}$ apart) for all speeds and nearly all angular positions, though it is not so easy to describe trends in the 2-BPF tone measurements for these two cases. Looking just at the asymmetric rod cases, we can also observe that the 1-BPF tone is greatest for Configuration 4 (8 rods irregularly placed), followed by Configuration 2 (6 rods $12^{\circ}$ apart), with Configuration 3 (15 rods $12^{\circ}$ apart) yielding the lowest 1-BPF tones for all speeds and nearly all angular positions in the far field. Again, trends in the 2 BPF tones are not as consistent.

Measured and predicted circumferential mode sound power levels are compared Figure 6 to 11 for all rod configurations and speeds tested. Figure 6 to 8 show the 1-BPF circumferential mode sound power levels, and Figures 9 to 11 show the 2-BPF sound power levels. Again, these predictions ignore the sound power distribution in the higher radial modes, ascribing all acoustic power to the first radial mode. This assumption may be acceptable for this fan in particular, but may prove to be inadequate for other fans. Measured sound power levels not predicted to be associated with the interaction of the rods and the rotor blades is generated by the interaction of the rotor blades with other non-uniformities in the flow, such as disturbances that may be caused by the struts securing the honeycomb in the ICD.

The good agreement between the predicted and the measured trends in mode sound power levels indicates that the tone noise produced by this fan depends primarily upon the number and the circumferential placement of the rods and blades. It is important to note that mode sound power levels calculations involve a summation, and that tone sound power levels are minimized by cancellations of terms in the summation. So while more circumferential modes may contribute to the tone noise generated by a circumferentially asymmetric arrangement of rods, not all modes expected to propagate within the duct are necessarily produced. This can be seen in the plots for Configuration 3 in Figures 6 to 8, for example, where both predictions and measurements indicate that odd circumferential modes dominate.

Inlet distortion tone noise predictions based on the Sofrin and Mathews' model do allow an engineer to quickly generate a parametric study to assess the potential impact of obstructions placed near a ducted fan rotor. What is gained in speed, though, may be lost in accuracy since sound power levels for all the radial modes expected to propagate are not calculated. Also, many design parameters that can be adjusted to optimize fan performance (axial distance between rotor and stator/rods, blade and vane shapes, etc.) are not included in this model. 


\section{Conclusion}

This paper describes a refinement to a fan inflow distortion tone noise prediction method based on theory first described by Sofrin and Mathews (Ref. 2) and extended by Koch (Ref. 1) for

circumferentially asymmetric distortion patterns. By assuming that each circumferential mode consists of a single radial mode (i.e., the first one), the cut-off ratios for this radial can be computed and used in the circumferential mode power level calculation. Circumferential mode power level predictions were compared to measurements for all the tested configurations and fan speeds. This predictive capability is another step towards developing tools to estimate the mode power levels produced by fans ingesting distorted inflow, an area of concern for those developing aircraft with embedded engines.

\section{References}

1. Koch, L.D., “An Experimental Study of Fan Inflow Distortion Tone Noise,” NASA/TM-2010215844, 2010.

2. Sofrin, T.G. and Mathews, D.C., “Asymmetric Stator Interaction Noise,” Journal of Aircraft, Vol. 17, No. 8, 1979, pp. 554-560.

3. Meyer, H.D. and Envia, E., “Aeroacoustic Analysis of Turbofan Noise Generation,” NASA/CR4715, 1996.

4. Loew, R.A., Lauer, J.T., McAllister, J. and Sutliff, D.L., “The Advanced Noise Control Fan,” NASA/TM-2006-214368, 2006.

5. Sutliff, D.L., "Rotating Rake Turbofan Duct Mode Measurement System,” NASA/TM-2005213828, 2005.

6. Tyler, J.M. and Sofrin, T.G., “Axial Flow Compressor Noise Studies,” Journal of Aircraft, Vol. 70, No. 8, 1962, pp. 309-332. 
TABLE 1.-ANGULAR POSITIONS OF RODS

\begin{tabular}{|c|c|l|}
\hline Config & Rods & \multicolumn{1}{|c|}{ Rod circumferential locations } \\
\hline 1 & 6 & $0^{\circ}, 60^{\circ}, 120^{\circ}, 180^{\circ}, 240^{\circ}, 300^{\circ}$ \\
\hline 2 & 6 & $0^{\circ}, 12^{\circ}, 24^{\circ}, 36^{\circ}, 336^{\circ}, 348^{\circ}$ \\
\hline 3 & 15 & $0^{\circ}, 12^{\circ}, 24^{\circ}, 36^{\circ}, 48^{\circ}, 60^{\circ}, 72^{\circ}, 84^{\circ}, 276^{\circ}, 288^{\circ}, 300^{\circ}, 312^{\circ}, 324^{\circ}, 336^{\circ}, 348^{\circ}$ \\
\hline 4 & 8 & $0^{\circ}, 12^{\circ}, 24^{\circ}, 108^{\circ}, 120^{\circ}, 192^{\circ}, 216^{\circ}, 348^{\circ}$ \\
\hline 5 & 0 & N/A \\
\hline
\end{tabular}

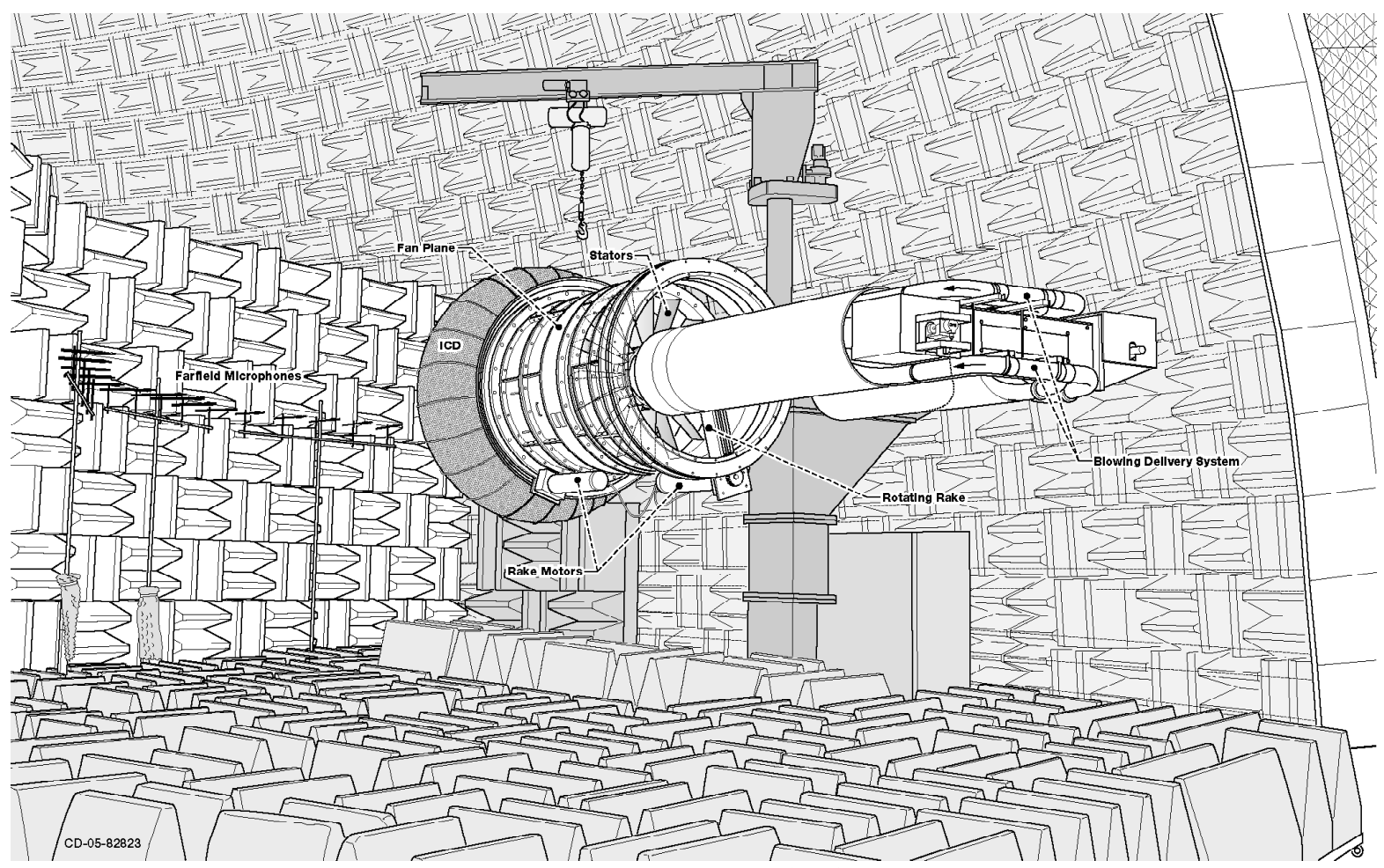

Figure 1.-The Advanced Noise Control Fan in the NASA Glenn AeroAcoustic Propulsion Lab.

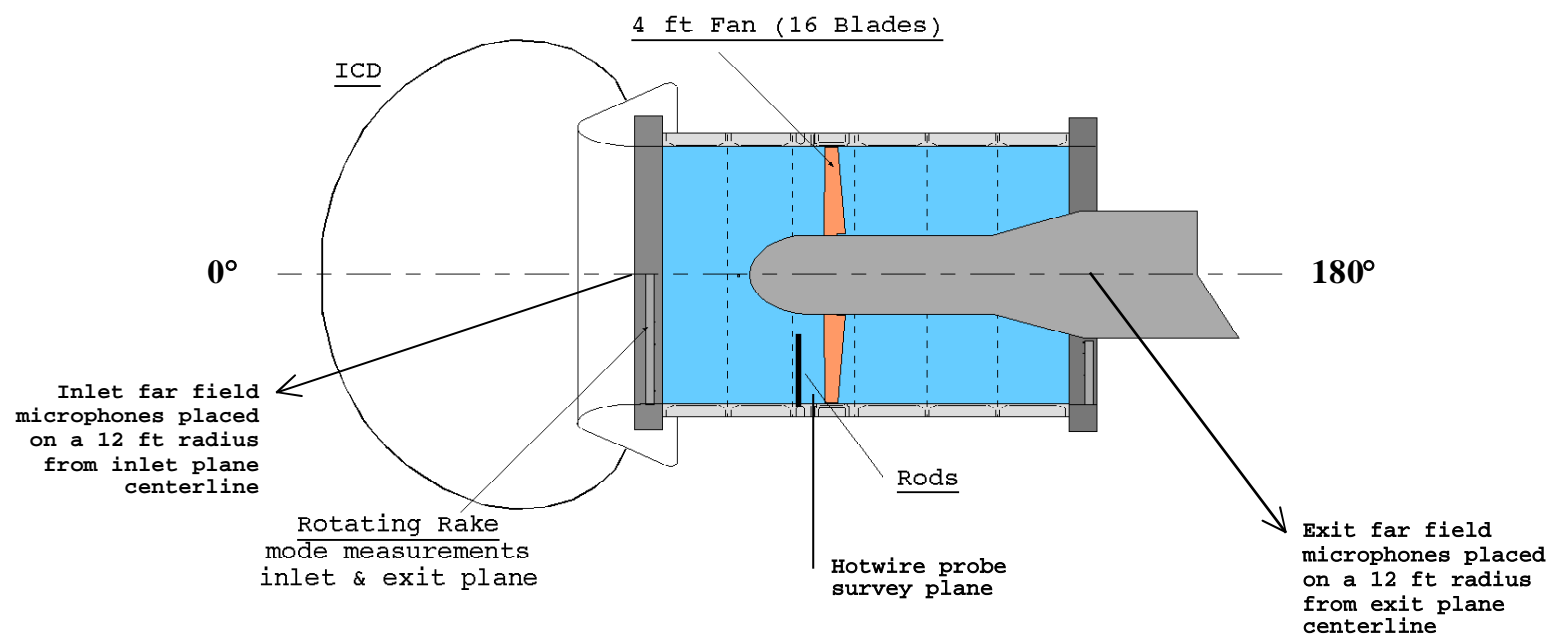

Figure 2.-Cross-sectional diagram of Advanced Noise Control Fan for the inlet distortion tests. 


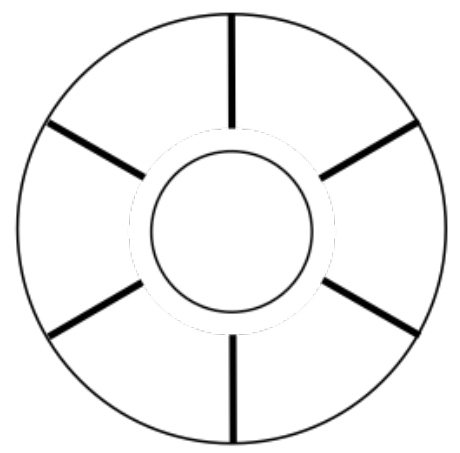

Configuration 1

6 rods $60^{\circ}$ apart

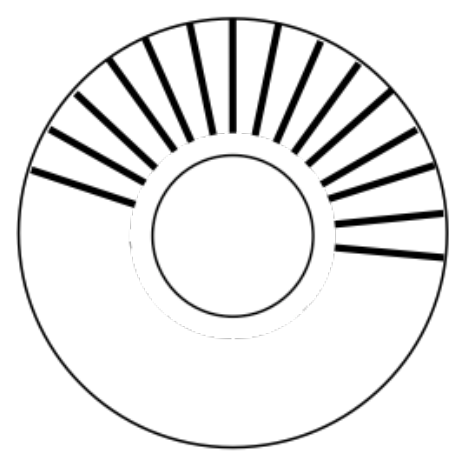

Configuration 3

15 rods $12^{\circ}$ apart

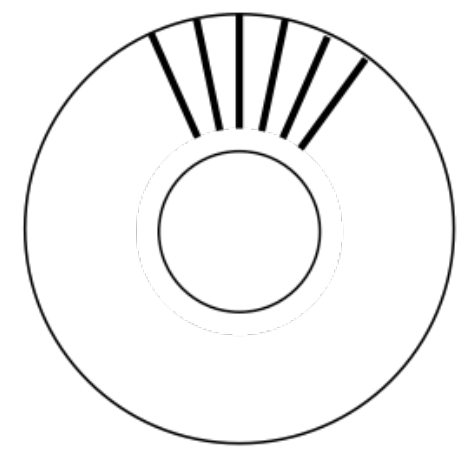

Configuration 2

6 rods $12^{\circ}$ apart

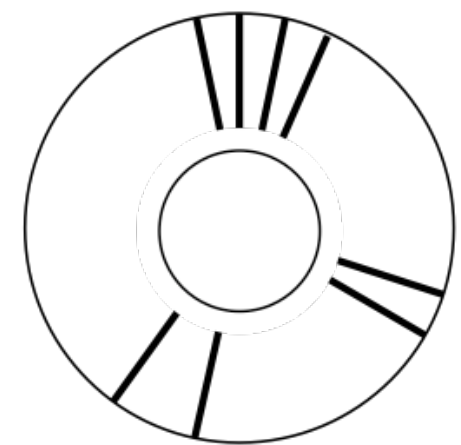

Configuration 4

8 rods integer multiples of $12^{\circ}$

Figure 3.-Circumferential locations of rods tested. 

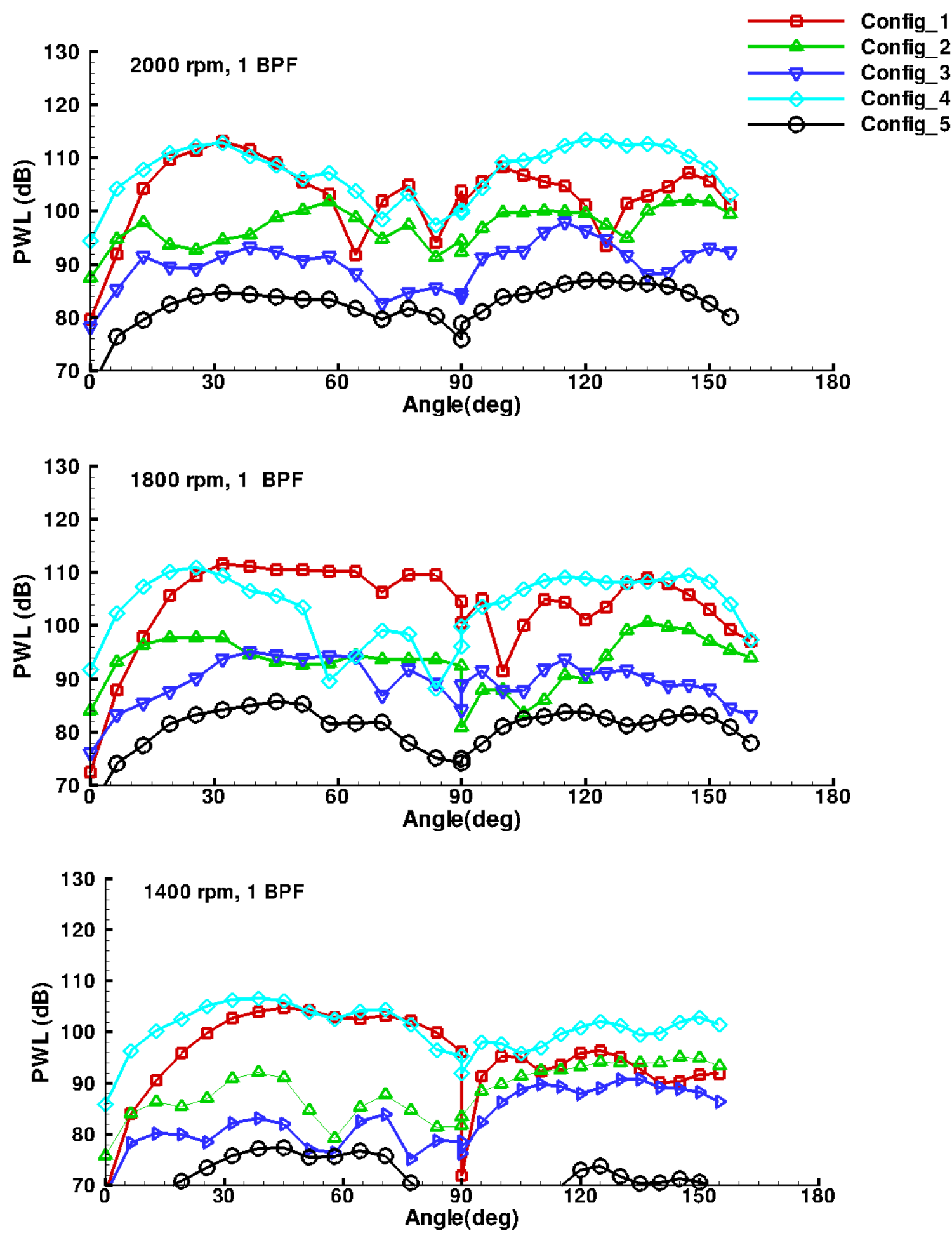

Figure 4.-Directivity plots for the 1-BPF tone for the three fan speeds tested. 

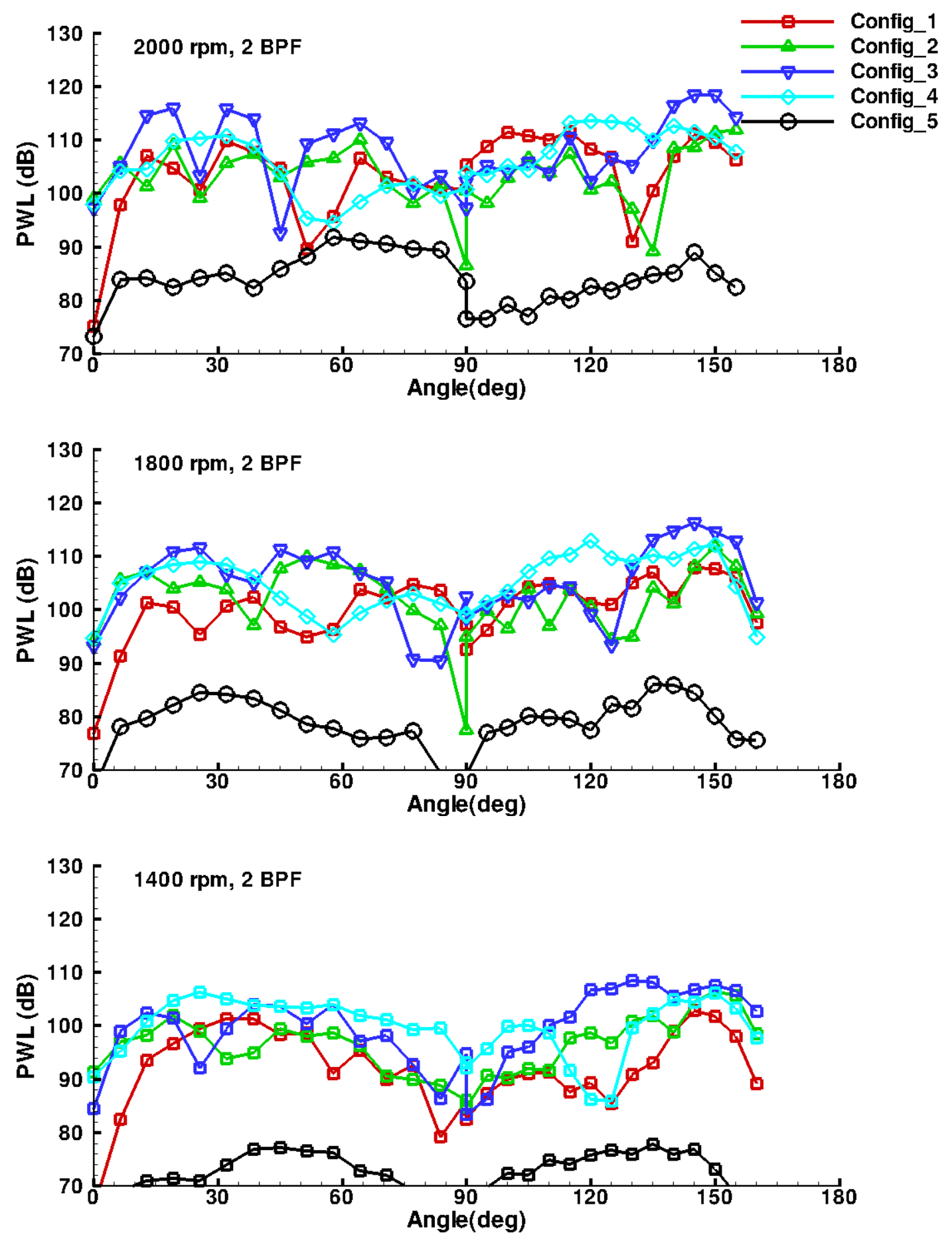

Figure 5.-Directivity plots for the 2-BPF tone for the three fan speeds tested. 

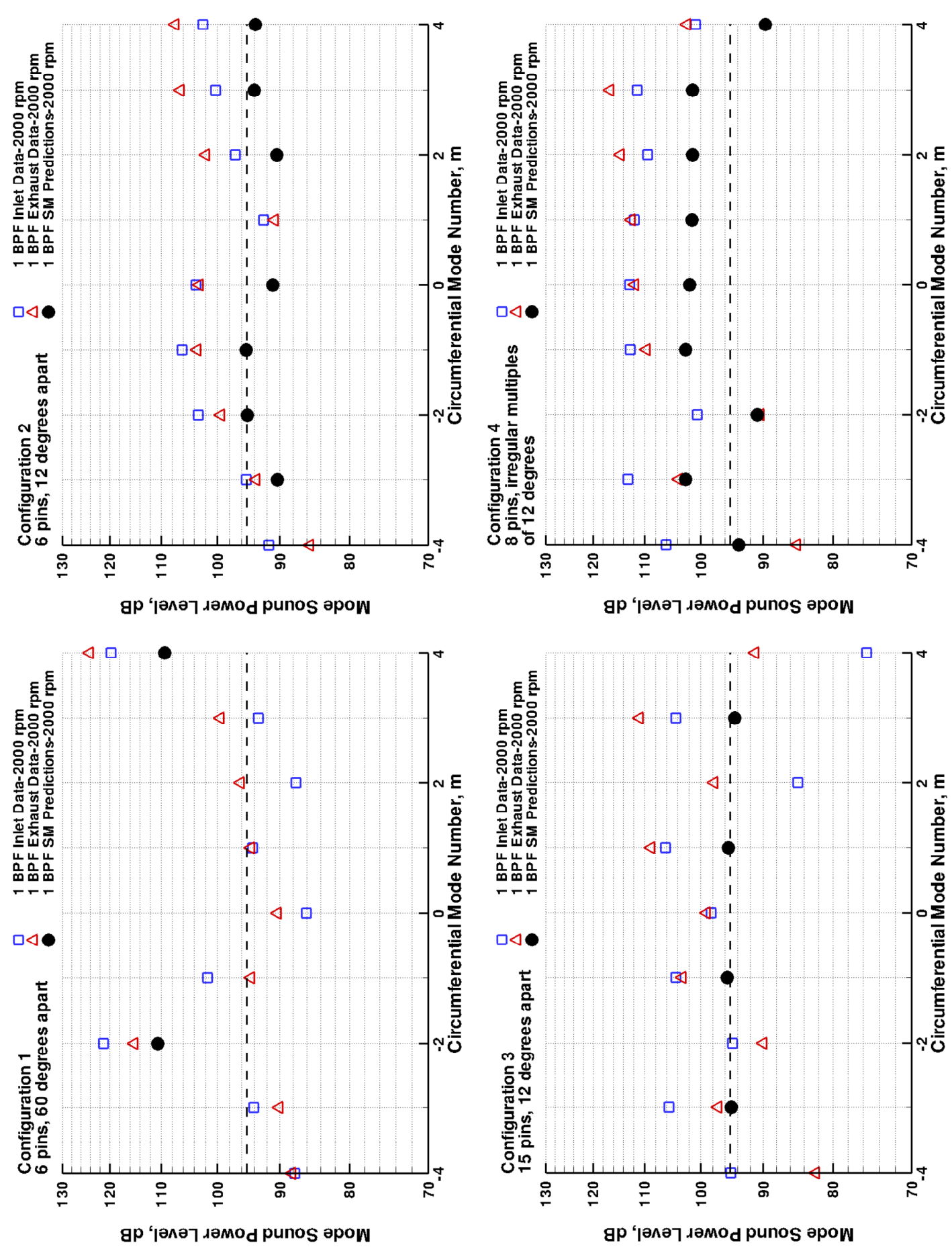

Figure 6.-Measured and predicted in-duct circumferential mode power levels-1 BPF, $2000 \mathrm{rpm}$. The dotted line indicates the noise floor for the data set. 

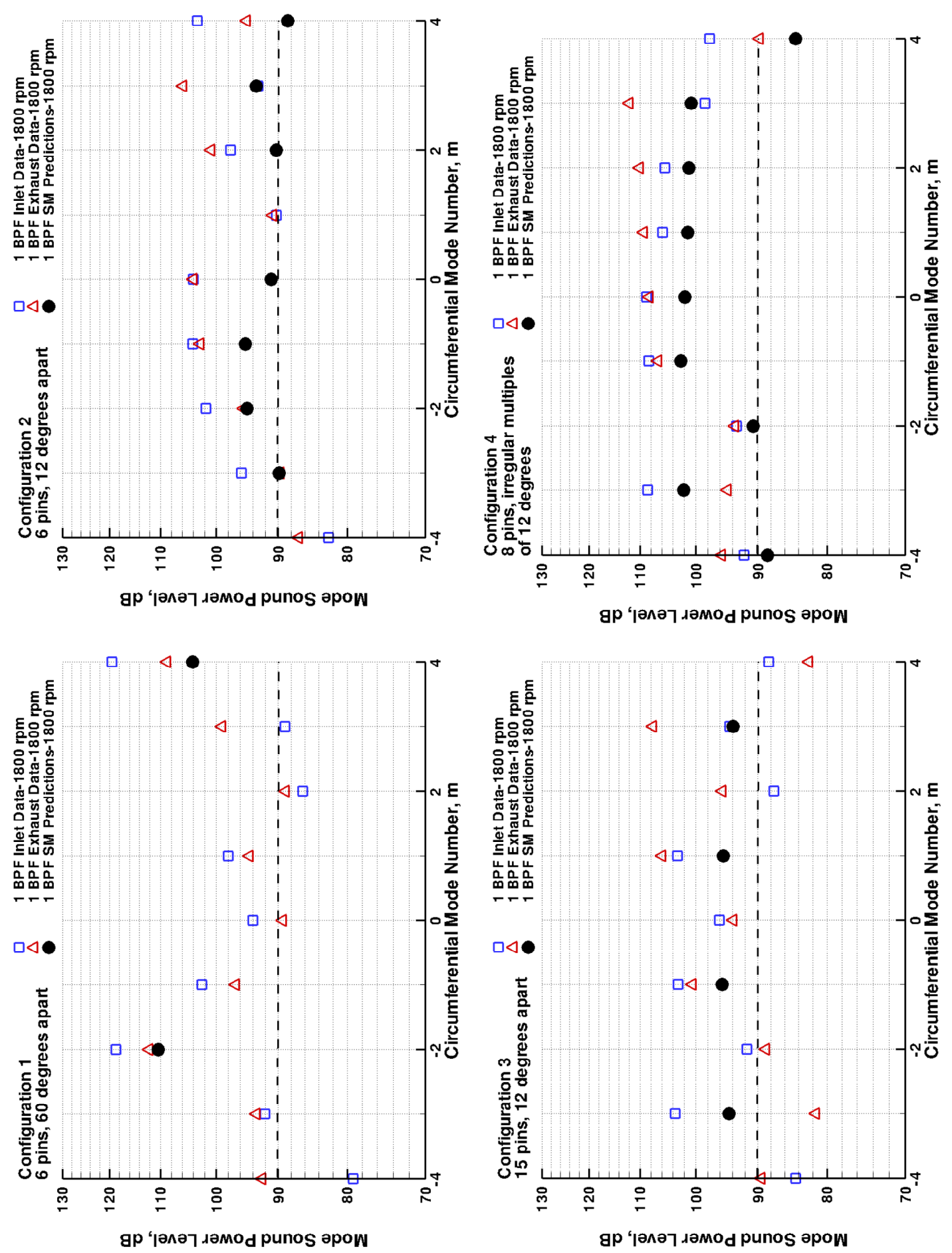

Figure 7.-Measured and predicted In-duct Circumferential Mode Power Levels-1 BPF, $1800 \mathrm{rpm}$. The dotted line indicates the noise floor for the data set. 

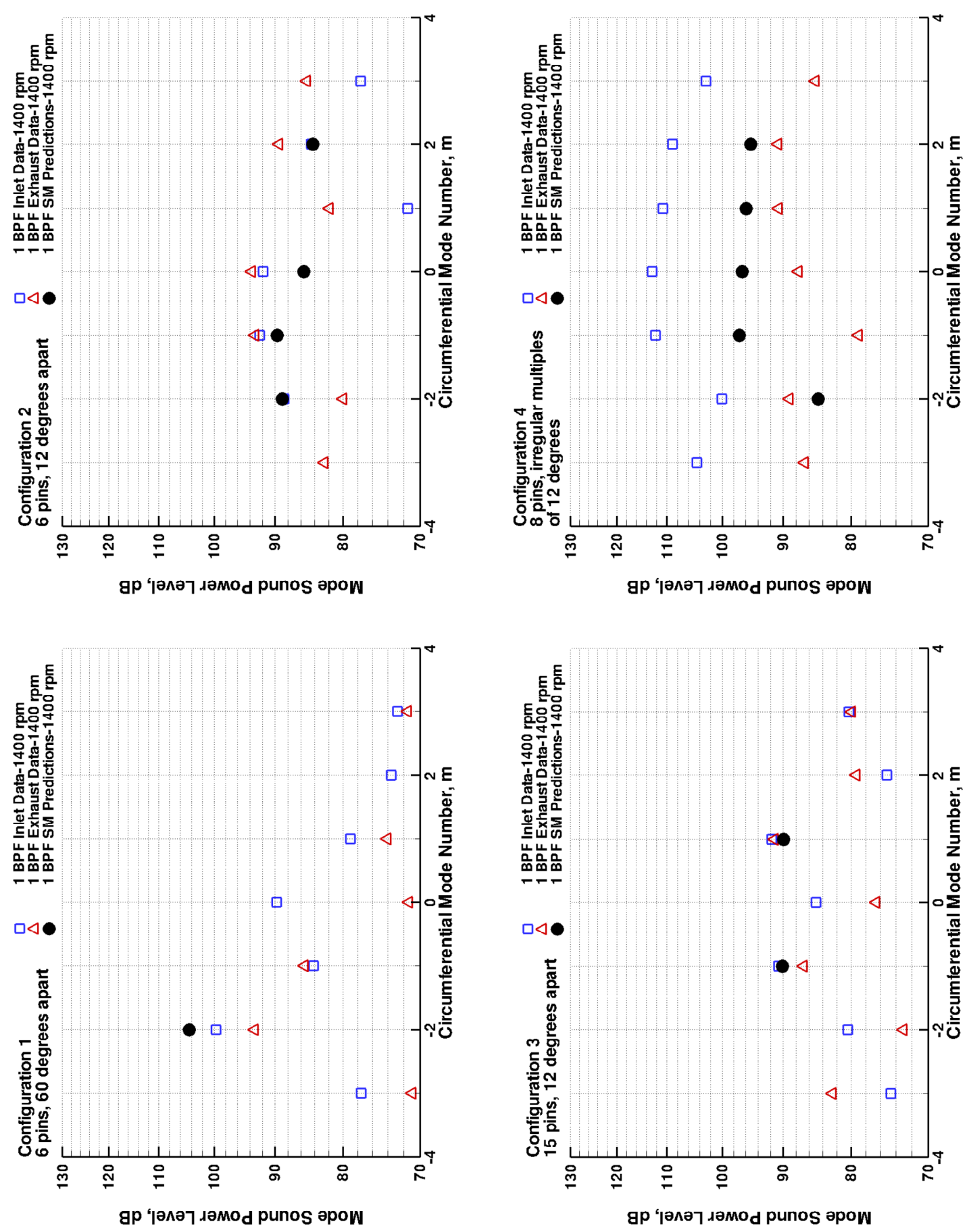

Figure 8.-Measured and predicted in-duct circumferential mode power levels-1 BPF, $1400 \mathrm{rpm}$. 

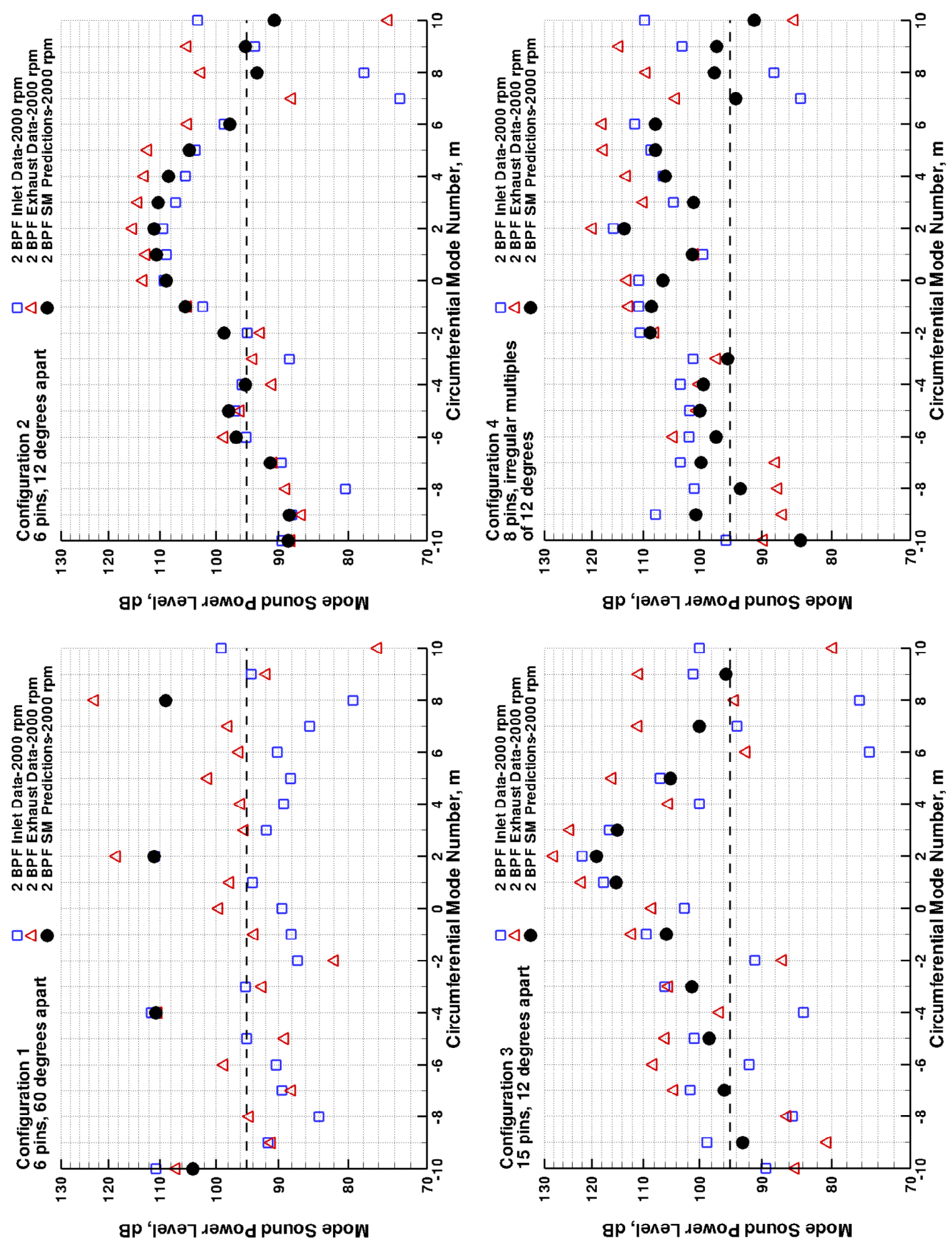

Figure 9.-Measured and predicted in-duct circumferential mode power levels-2 BPF, $2000 \mathrm{rpm}$. The dotted line indicates the noise floor for the data set. 

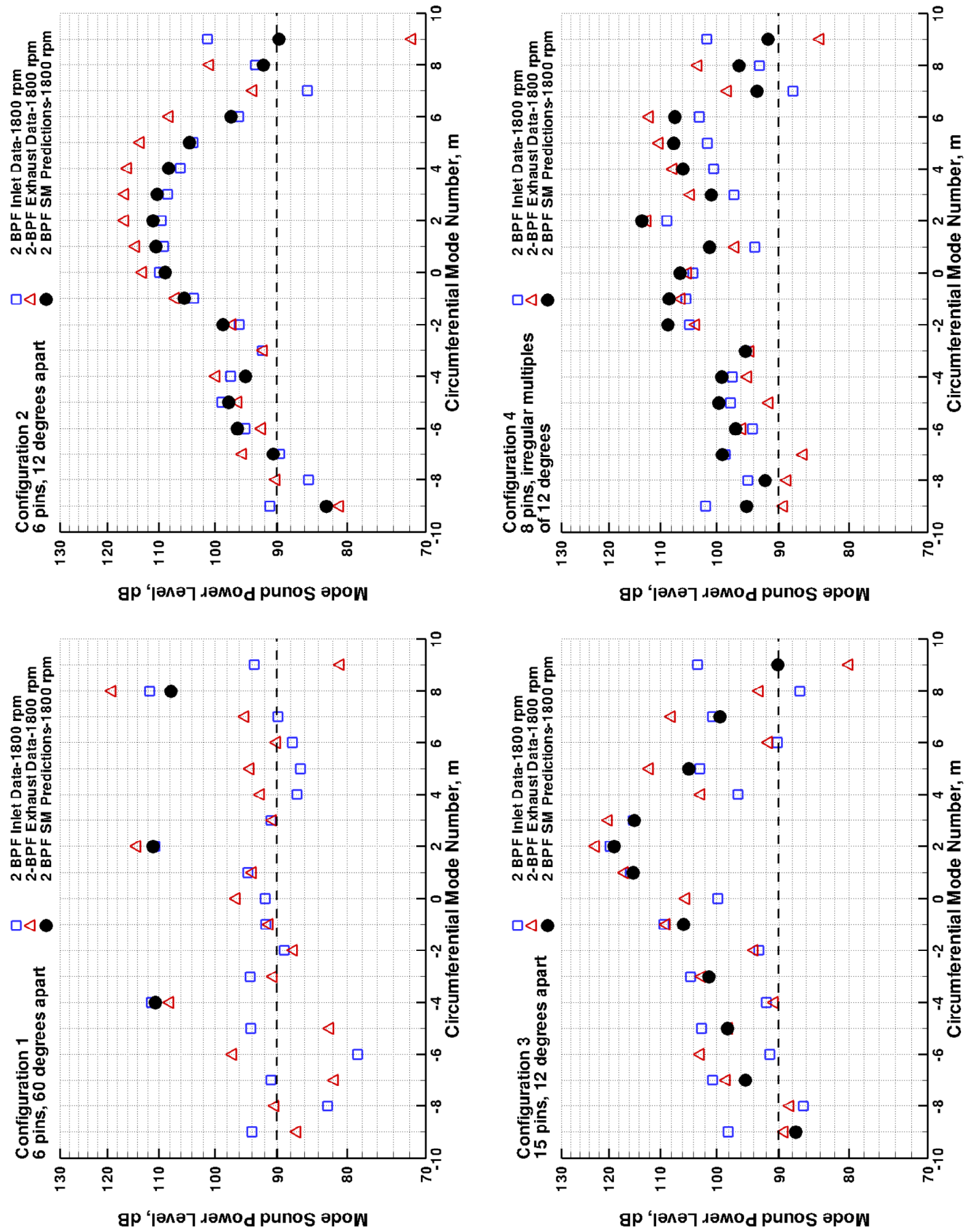

Figure 10.-Measured and predicted in-duct circumferential mode power levels-2 BPF, $1800 \mathrm{rpm}$. The dotted line indicates the noise floor for the data set. 

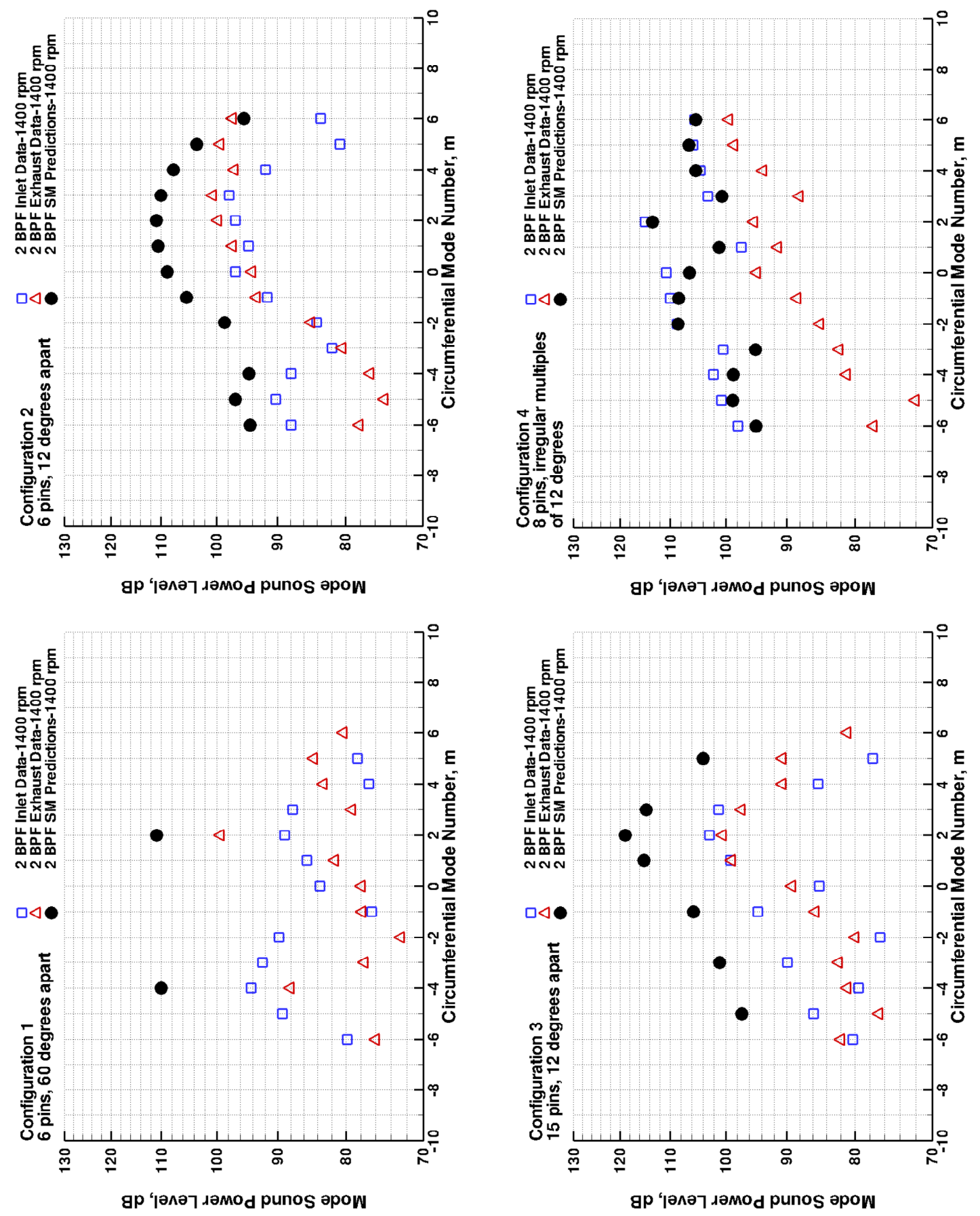

Figure 11.-Measured and predicted in-duct circumferential mode power levels-1 BPF, $1400 \mathrm{rpm}$. 


\begin{tabular}{|c|c|c|}
\hline \multicolumn{2}{|c|}{ REPORT DOCUMENTATION PAGE } & $\begin{array}{l}\text { Form Approved } \\
\text { OMB No. 0704-0188 }\end{array}$ \\
\hline \multicolumn{3}{|c|}{$\begin{array}{l}\text { The public reporting burden for this collection of information is estimated to average } 1 \text { hour per response, including the time for reviewing instructions, searching existing data sources, gathering and maintaining the } \\
\text { data needed, and completing and reviewing the collection of information. Send comments regarding this burden estimate or any other aspect of this collection of information, including suggestions for reducing this } \\
\text { burden, to Department of Defense, Washington Headquarters Services, Directorate for Information Operations and Reports (0704-0188), } 21215 \text { Jefferson Davis Highway, Suite } 1224 \text {, Arlington, VA } 22222-24302 \text {. } \\
\text { Respondents should be aware that notwithstanding any other provision of law, no person shall be subject to any penalty for failing to comply with a collection of information if it does not display a currently valid OMB } \\
\text { control number. } \\
\text { PLEASE DO NOT RETURN YOUR FORM TO THE ABOVE ADDRESS. }\end{array}$} \\
\hline $\begin{array}{l}\text { 1. REPORT DATE (DD-MM-YYYY) } \\
01-08-2010\end{array}$ & $\begin{array}{l}\text { 2. REPORT TYPE } \\
\text { Technical Memorandum }\end{array}$ & 3. DATES COVERED (From - To) \\
\hline \multirow{3}{*}{\multicolumn{2}{|c|}{$\begin{array}{l}\text { 4. TITLE AND SUBTITLE } \\
\text { Predicted and Measured Modal Sound Power Levels for a Fan Inges }\end{array}$}} & 5a. CONTRACT NUMBER \\
\hline & & 5b. GRANT NUMBER \\
\hline & & 5c. PROGRAM ELEMENT NUMBER \\
\hline \multirow{3}{*}{\multicolumn{2}{|c|}{$\begin{array}{l}\text { 6. AUTHOR(S) } \\
\text { Koch, L., Danielle }\end{array}$}} & 5d. PROJECT NUMBER \\
\hline & & 5e. TASK NUMBER \\
\hline & & $\begin{array}{l}\text { 5f. WORK UNIT NUMBER } \\
\text { WBS 561581.02.08.03.18.03 }\end{array}$ \\
\hline \multicolumn{2}{|c|}{$\begin{array}{l}\text { 7. PERFORMING ORGANIZATION NAME(S) AND ADDRESS(ES) } \\
\text { National Aeronautics and Space Administration } \\
\text { John H. Glenn Research Center at Lewis Field } \\
\text { Cleveland, Ohio 44135-3191 }\end{array}$} & $\begin{array}{l}\text { 8. PERFORMING ORGANIZATION } \\
\text { REPORT NUMBER } \\
\text { E-17409 }\end{array}$ \\
\hline \multirow{2}{*}{\multicolumn{2}{|c|}{$\begin{array}{l}\text { 9. SPONSORING/MONITORING AGENCY NAME(S) AND ADDRESS(ES) } \\
\text { National Aeronautics and Space Administration } \\
\text { Washington, DC 20546-0001 }\end{array}$}} & $\begin{array}{l}\text { 10. SPONSORING/MONITOR'S } \\
\text { ACRONYM(S) } \\
\text { NASA }\end{array}$ \\
\hline & & $\begin{array}{l}\text { 11. SPONSORING/MONITORING } \\
\text { REPORT NUMBER } \\
\text { NASA/TM-2010-216782 }\end{array}$ \\
\hline \multicolumn{3}{|c|}{$\begin{array}{l}\text { 12. DISTRIBUTION/AVAILABILITY STATEMENT } \\
\text { Unclassified-Unlimited } \\
\text { Subject Categories: } 02 \text { and } 71 \\
\text { Available electronically at http://gltrs.grc.nasa.gov } \\
\text { This publication is available from the NASA Center for AeroSpace Information, 443-757-5802 }\end{array}$} \\
\hline
\end{tabular}

\section{SUPPLEMENTARY NOTES}

\section{ABSTRACT}

Refinements have been made to a method for estimating the modal sound power levels of a ducted fan ingesting distorted inflow. By assuming that each propagating circumferential mode consists only of a single radial mode (the one with the highest cut-off ratio), circumferential mode sound power levels can be computed for a variety of inflow distortion patterns and operating speeds. Predictions from the refined theory have been compared to data from an experiment conducted in the Advanced Noise Control Fan at NASA Glenn Research Center. The inflow to the fan was distorted by inserting cylindrical rods radially into the inlet duct. The rods were placed at an axial location one rotor chord length upstream of the fan and arranged in both regular and irregular circumferential patterns. The fan was operated at 2000, 1800, and $1400 \mathrm{rpm}$. Acoustic pressure levels were measured in the fan inlet and exhaust ducts using the Rotating Rake fan mode measurement system. Far field sound pressure levels were also measured. It is shown that predicted trends in circumferential mode sound power levels closely match the experimental data for all operating speeds and distortion configurations tested. Insight gained through this work is being used to develop more advanced tools for predicting fan inflow distortion tone noise levels.

\section{SUBJECT TERMS}

Fans; Noise

\begin{tabular}{|c|c|c|c|c|c|}
\hline \multicolumn{3}{|c|}{ 16. SECURITY CLASSIFICATION OF: } & \multirow{2}{*}{$\begin{array}{l}\text { 17. LIMITATION OF } \\
\text { ABSTRACT } \\
\text { UU }\end{array}$} & \multirow{2}{*}{$\begin{array}{l}\text { 18. NUMBER } \\
\text { OF } \\
\text { PAGES } \\
21\end{array}$} & \multirow{2}{*}{$\begin{array}{l}\text { 19a. NAME OF RESPONSIBLE PERSON } \\
\text { STI Help Desk (email:help@sti.nasa.gov) } \\
\text { 19b. TELEPHONE NUMBER (include area code) } \\
\text { 443-757-5802 }\end{array}$} \\
\hline $\begin{array}{l}\text { a. REPORT } \\
\text { U }\end{array}$ & $\begin{array}{l}\text { b. ABSTRACT } \\
U\end{array}$ & $\begin{array}{l}\text { c. THIS } \\
\text { PAGE } \\
\text { U }\end{array}$ & & & \\
\hline
\end{tabular}



